Jurij Fedoryk

\title{
Liczebność i struktura wewnętrzna duchowieństwa prawosławnego w wikariacie lubelskim w latach 1875-1905
}

Można przedstawić wiele kryteriów różnicujących duchowieństwo prawosławne w Królestwie Polskim w 1875 roku. Najistotniejszy jest jednak podział na duchowieństwo byłej eparchii warszawsko-nowogeorgiewskiej i kler pounicki. Głównym zadaniem tego ostatniego była praca z ludnością pounicką.

Byli księża uniccy zlikwidowanej diecezji chełmskiej stanowili większość duchowieństwa prawosławnego Królestwa Polskiego po roku 1875. Jednak, wraz ze zmianami w strukturze dekanalno-parafialnej eparchii w latach 1875-1905, zmieniały się również liczba i skład miejscowego kleru. Na początku 1875 roku na terenie parafii wchodzących w skład unickiej diecezji chełmskiej pracowało 271 duchownych Spośród tej liczby kapłanów tylko 191 księży zgodziło się przejść na prawosławie. Zdecydowana ich większość pochodziła z Galicji, składając się z księży i byłych alumnów Chełmskiego Seminarium Duchownego, sprowadzonych do diecezji chełmskiej w okresie reform obrządkowych w latach 1864-1875².

Reformy organizacyjne, dotyczące przekształcenia unickiej Cerkwi na prawosławną, wpłynęły na zmianę kształtu nowo powstałej eparchii. Od czasu przyłączenia unitów do prawosławia, na terenie Królestwa Polskiego utworzona została nowa, chełmsko-warszawska diecezja prawosławna, składająca się z dwóch części. Pierwsza obejmowała parafie „dawnie prawosławne” (driewleprawosławne) z centrum w Warszawie, obsadzone przez ludność napływową, m.in. wojskowych i urzędników carskich. Drugą część stanowiły byłe parafie pounickie i weszła ona w skład tzw. wikariatu lubelskiego, autonomicznej jednostki w eparchii chełmsko-warszawskiej, kierowanej z Chełma². W ciągu następnych 30 lat liczba księży wikariatu lubelskiego stale wzrastała, czego przyczyną z jednej strony był ogólny wzrost liczby parafii,

${ }^{1} 64$ spośród nich zostało internowanych, 9 nie pracowało na parafiach i jeszcze 10 było emerytami. Zob.: W. Kołbuk, Duchowieństwo unickie w Królestwie Polskim 1835-1875, Lublin 1992, s. 24.

${ }^{2}$ Zbiór praw. Postanowienia i rozporządzenia Rządu w Guberniach Królestwa Polskiego obowiazujace. Wydane po zniesieniu w 1871 roku urzędowego wydania Dziennika Praw Królestwa Polskiego, t. 5, cz. 1 za 1875 rok, oprac. F. Jeziorański, Warszawa 1879, s. 318-323. 
z drugiej zaś skierowanie duchowieństwa do placówek nieobsadzonych przed rokiem 1875. W 1884 roku w parafiach wikariatu działało 298 księży, w 1891 - 301, w 1897 liczba ta powiększyła się do 302, by w 1904 osiągnąć 31333.

Warto zaznaczyć, że na charakter tych zmian wpłynęło również włączenie w ramy wikariatu lubelskiego parafii oraz duchowieństwa wcześniej należących do eparchii warszawsko- nowogeorgiewskiej. Wśród nich znajdowały się trzy parafie pounickie, które wcześniej przeszły na prawosławie: Babice, Górny Potok i Luchów, oraz ,dawnie prawosławne” parafie miejskie, znajdujące się na terenie byłej diecezji chełmskiej. Z drugiej strony duchowieństwo dziewięciu cerkwi pounickich guberni suwalskiej i łomżyńskiej oraz cerkwi Uspieńskiej w Warszawie należało do wikariatu lubelskiego tylko do 23-25 stycznia 1879 roku, kiedy mocą rozporządzenia władz eparchii chełmsko-warszawskiej parafie te zostały podporządkowane bezpośredniemu zarządowi arcybiskupa Leoncjusza i konsystorza chełmsko-warszawskiego ${ }^{4}$.

Liczba kleru w parafiach prawosławnych zależała od ich wielkości. Zgodnie z zatwierdzoną uchwałą Rady Państwa z dnia 29 maja (10 czerwca) 1876 roku, dotyczącą projektu ustanawiania etatów prawosławnych cerkwi parafialnych byłej diecezji chełmskiej, w miejscowościach z liczbą wiernych powyżej 2000 osób miały zostać utworzone posady pomocnika proboszcza oraz młodszego psalmisty. Jednocześnie, zgodnie z wymogami obsady parafii wikariatu lubelskiego, przy czternastu cerkwiach miejskich guberni lubelskiej i siedleckiej oraz w Mazowiecku w guberni łomżyńskiej musiały powstać etaty diakonów ${ }^{5}$. Najwięcej stanowisk otrzymały byłe unickie cerkwie w Białej Podlaskiej, Hrubieszowie, Warszawie i we Włodawie. W skład obsady tych parafii wchodzili: proboszcz, pomocnik, diakon i dwóch psalmistów (soborna cerkiew w Białej miała dwóch pomocników proboszcza i trzech psalmistów) ${ }^{6}$. Wśród duchowieństwa parafialnego wyróżnić należy emerytów oraz księży zwolnionych z etatów ze względów zdrowotnych. Czasem księżmi pozaetatowymi byli również młodzi, niedoświadczeni zawodowo absolwenci seminarium?

Po likwidacji unii, władze zwróciły szczególną uwagę na sprawę obsadzenia parafii wakujących. Jak podaje Witold Kołbuk, w 1864 roku istniało 121 parafii bez proboszczów, co stanowiło 44,8\% ogólnego ich stanu w diecezji chełmskiej. W cza-

\footnotetext{
${ }^{3}$ Archiwum Państwowe w Lublinie, Klirovyje Vedomosti (dalej: APL, KV), sygn. 20, 30, 41, 52, $69,81,90,103,128,139,149,161,180,202,213,234,281,293,303,316,335,347,358,372,389,412$, $426,434,444,462,474,484,497,516,537,547,558,569,589,617,630,633,666,679,699,708,719$, $729,754,766,774,786,807,817,827,837,852,863,873,884,906,917,927,939,956,963,972,981$, 992, 1015, 1026, 1037, 1049.

${ }^{4}$ „Chołmsko-Warszawskij Jeparchialnyj Wiestnik”, 1879, nr 4, s. 54.

${ }^{5}$ Zbiór praw. Postanowienia i rozporządzenia Rządu w Guberniach Królestwa Polskiego obowiazujace. Wydane po zniesieniu w 1871 roku urzędowego wydania Dziennika Praw Królestwa Polskiego, t. 10 , cz. 3 za 1876 rok, oprac. S. Godlewski, Warszawa 1882, s. 120-126.

${ }^{6}$ Tamże.

${ }^{7}$ Przykładem księży znajdujących się poza etatem w młodym wieku mogą być Jewstafij Aleksandrowicz ze Świerszczowa (1881-1884) czy Jan Jaroszewicz z praskiej cerkwi w Warszawie (1892-1894). Zob.: APL, KV, sygn. 839, 1015.

${ }^{8}$ W. Kołbuk, dz. cyt., s. 25.
} 
sie „reform obrządku unickiego” i aktywnego sprowadzania księży z Galicji ilość takich parafii zmniejszyła się do 64 i 31 w latach 1867 i $1872^{9}$. Ale już w latach 1872-1875 miał miejsce proces odwrotny. W tym czasie liczba parafii nieobsadzonych powiększyła się do $62^{10}$. Trudno ustalić wszystkie przyczyny tych zmian, ale można przypuszczać, że wśród istotniejszych powodów tego zjawiska były ucieczka „opornych” księży do Galicji oraz powiększenie obszaru parafii unickich. Po likwidacji unii puste parafie pounickie zaczęto obsadzać nowymi księżmi z Galicji oraz pierwszymi przybyszami z Cesarstwa, dzięki czemu problem parafii nieobsadzonych został praktycznie rozwiązany - już w roku 1878 prawie wszystkie parafie wikariatu lubelskiego miały własnych proboszczów. W dalszych latach do duchowieństwa chełmsko-warszawskiego dołączyli księża nowo powstałych probostw oraz byłych parafii „,awnie prawosławnych”, przyłączonych do dekanatów wikariatu lubelskiego ${ }^{11}$.

W latach 1875-1905 nastąpiły wyraźne zmiany w strukturze wiekowej duchowieństwa wikariatu. Po 1864 roku zaczął się etap odmładzania składu księży unickich. Proces ten, trwający aż do końca lat 70., stał się przyczyną gwałtownego powiększenia się liczby księży w wieku 20-30 lat. Młodzi duchowni oraz niedawni seminarzyści pochodzenia galicyjskiego nie tylko trafiali do parafii nieobsadzonych, ale również masowo zajmowali miejsca „opornych” i niepewnych księży miejscowych.

Jak zostało to przedstawione w tabeli 1., w roku 1877 aż 35,25\% księży należało do grupy wiekowej do lat $30^{12}$. W miarę stabilizowania się liczby duchowieństwa politycznie poprawnego zwiększał się średni wiek księży. W 1904 roku wśród duchowieństwa wikariatu dominowała już grupa księży w wieku 50-60 lat. Jak widać, w omawianym okresie większość stanowili duchowni urodzeni w latach 40. Duży odsetek stanowili księża galicyjscy, którzy przybyli do Królestwa Polskiego w latach 60. i 70. Zmiany demograficzne wśród duchowieństwa wikariatu lubelskiego przedstawiają tabela 1. i diagram 1.

Szczególną cechą duchowieństwa prawosławnego w wikariacie lubelskim był jego podział na różne grupy. Istnienie na Chełmszczyźnie i Podlasiu w latach 18751905 trzech grup, tzn. duchowieństwa miejscowego, „Galicjan” i wychodźców z Cesarstwa, było skutkiem carskiej polityki rusyfikacji byłej eparchii chełmskiej. Wielką rolę w tych planach miało odegrać obsadzenie parafii pounickich księżmi

${ }^{9}$ APL, Chełmski Konsystorz Prawosławny, sygn. 1050, k. 1.

${ }^{10}$ Tamże, brak pag.

${ }^{11}$ Wśród byłych ,dawnie prawosławnych” parafii, przyłączonych do dekanatów wikariatu lubelskiego, były: Biała (cerkiew Cyryla i Metodego) do dekanatu I bialskiego; Babice, Luchów, Potok Górny i Tarnogród (cerkiew Uspieńska) do dekanatu biłgorajskiego (od 1899 roku do II biłgorajskiego); Chełm (cerkiew Jana Teologa) do dekanatu II chełmskiego (po 1899 roku); Hrubieszów (cerkiew św. Mikołaja) do dekanatu I hrubieszowskiego; Iwangorod, Janów Lubelski, Lublin (cerkiew Wzniesienia Krzyża) i Nowa Aleksandria do dekanatu lubelskiego; Drohiczyn, Grodzisk, Łuków i Siedlce do dekanatu siedleckiego; Zamość (Jezusa Zbawiciela) do dekanatu zamojskiego.

12 Patrz tabela 1. 
Jurij Fedoryk

politycznie wiarygodnymi. W latach poprzedzających likwidację unii znaczna grupa księży miejscowych była zmuszona do opuszczenia parafii. Do duchowieństwa zwolnionego z parafii należeli zarówno księża sympatyzujący ze starym obrządkiem unickim, zbliżonym do łacińskiego, jak i ci, którzy nie pogodzili się z przejściem na prawosławie, chociaż wcześniej wykonywali wszelkie rozporządzenia władz. Wśród pierwszych znaleźli się tzw. oporni, uważani przez władze za fanatyków-polonofilów. Między nimi była i grupa duchownych dekanatu radzyńskiego, zwolnionych w marcu 1874 roku: Jan Mazanowski, Grzegorz Wasilewski, Faustyn Hanytkiewicz, Andrzej Horoszewicz, Michał Szulakiewicz, Leon Szymański, Szymon Łącki i Jan Bojarski. Z drugiej grupy warto wymienić Antoniusza Lebedyńskiego, Grzegorza Kurmanowicza, Bazylego Budiłowicza, braci Leonarda i Waleriana Charłampowiczów i Michała Zatkalika ${ }^{13}$. Spośród byłych księży unickich 66 duchownych wyemigrowało do Galicji, a 74 zostało internowanych poza terenami zamieszkanymi przez byłych unitów, gdzie przebywali pod pilnym nadzorem policji14. Zarówno duchowni internowani, jak i znajdujący się na przymusowej emigracji znaleźli się w ciężkiej sytuacji materialnej. Nawet tak zasłużeni w dziele „oczyszczenia obrządku” jak przykładowo ksiądz Lebedyński mieli dochód w wysokości zaledwie 150 rubli rocznie. Mieszkając poza obszarami zamieszkanymi przez byłych unitów, oderwani od rodzin, kończyli życie w smutku i biedzie. Wspomniany wyżej Lebedyński trafił na zesłanie podobnie jak księża „oporni”, i nie pomogło ani to, że miał syna, który przeszedł na prawosławie i awansował na posadę urzędnika celnego, ani osobiste

\footnotetext{
${ }^{13}$ Antoniusz Lebedyński, były proboszcz w Podhorcach (dek. hrubieszowski), otrzymał zwolnienie z parafii w związku z własnym podaniem, napisanym 7 maja 1875 roku. Przebywając przez 29 lat na służbie duchownej, został pozytywnie scharakteryzowany przez władze gubernialne jako wierny wobec ruskiej narodowości. Mimo tego deportowano go do Zawichostu (gub. radomska). Podobnie było z byłym proboszczem Parczewa Michałem Zatkalikiem. Inni księża, Grzegorz Kurmanowicz czy bracia Charłampowicze, również działający w „duchu narodowości ruskiej”, nie chcąc wyrzekać się unii, zbiegli do Galicji, gdzie otrzymali parafie. Zob.: APL, Kancelaria Gubernatora Lubelskiego (dalej: KGL), sygn. 1876:33, k. 1-6; 1883:240, k. 1-3; 1904:167, k. 1-2; tamże, APL, Chełmski Konsystorz Greckokatolicki, sygn. 1202, k. 66, 110, 156; tamże, APL, Chełmski Zarząd Duchowny, sygn. 64, k. 49.

${ }^{14}$ Los „,chołmszczaków”, którzy uciekli do Galicji, nie był łatwy. Wielu z nich starało się o pracę na parafiach miejscowych. Przez długi czas warunkiem otrzymania prawa sprawowania mszy świętej w parafiach unickich Galicji było zdanie specjalnego egzaminu konkursowego. Wśród osób ubiegających się o złożenie egzaminu przed lwowskim ordynariatem metropolitarnym znalazła się m.in. grupa 22 najbardziej znanych „opornych” księży (wśród nich: Emilian Bańkowski, Jan Bojarski, Jan Charłampowicz, Michał Harasowski, Mikołaj Sebowicz etc.) Egzaminy konkursowe dla wychodźców z Rosji trwały do 10 stycznia 1876 roku, dopóki nie zostały zniesione przez papieża. W latach 1874 i 1876 Ojciec Święty przysłał im pomoc pieniężną w wysokości 5000 i 6000 florenów. Ułatwiło to nieco „chołmszczakom” znalezienie pracy w Galicji, nie miało jednak wpływu na wrogie nastawienie do nich przedstawicieli ruskich elit narodowych, którzy uważali księży z Królestwa Polskiego za renegatów własnej narodowości i sprzymierzeńców miejscowych polonofilów. To poczucie Rusinów halickich wynikało z wielkiej uwagi i sympatii, jakie Polacy w Galicji okazywali zlatynizowanym księżom unickim, obdarzonym aureolą męczeństwa Kościoła katolickiego w Rosji. Zob.: Lvivśka Nacionalna Biblioteka, Narodnyj Dim, sygn. 135/23, k. 1-3; A. Boudou, Stolica Święta a Rosja. Stosunki dyplomatyczne między niemi w XIX stuleciu, t. 2: 1848-1883, Kraków 1930, s. 522; W. Osadczy, Święta Ruś. Rozwój i oddziaływanie idei prawosławia w Galicji, Lublin 2007, s. 231.
} 
poparcie dziekana biłgorajskiego, a nawet biskupa lubelskiego (Modesta) ${ }^{15}$. Zarzuty i drwiny ze strony księży, deportowanych za opór, wzmacniały poczucie upokorzenia. Ci zaś duchowni, którzy zbiegli do Galicji, czuli się obco wśród miejscowego duchowieństwa i mimo sympatii ,partii polskiej”, a nawet samego Rzymu, egzystowali w niesprzyjających warunkach finansowych, cierpiąc ponadto z powodu nostalgii za Chełmszczyzną. Niektórzy z „,chołmszczaków”, jak Leonard i Walerian Charłampowiczowie, prosili o zgodę na powrót do byłej diecezji chełmskiej, ale dostali odpowiedź odmowną, mimo że do czasu „ucieczki” za granicę nie przeciwdziałali polityce ,reform obrządku grecko-unickiego" "16.

Zamiast ,politycznie niewiarygodnych” kapłanów, w latach 1865-1875 do diecezji chełmskiej przybyło 51 księży pochodzenia galicyjskiego. Dodatkowo 60 seminarzystów pochodzenia galicyjskiego zostało wyświęconych po studiach w Chełmskim Seminarium Duchownym ${ }^{17}$. To, że nowo przybyli moskalofile będą gorliwie wykonywać wszelkie rozporządzenia, nie budziło najmniejszych wątpliwości władz, będących pod wrażeniem ich wcześniejszego zaangażowania w sprawę delatynizacji Kościoła greckokatolickiego w Galicji. Jako naturalni przeciwnicy polskich roszczeń wobec tzw. ziem ruskich, Galicjanie mieli stać się wiernymi sprzymierzeńcami rusyfikacyjnej polityki caratu na Chełmszczyźnie i Podlasiu. Wielu z nich było gorącymi zwolennikami jak najszybszej kasaty unii i jak najszybszego włączenia unitów do prawosławia. Zaufanie, jakim cieszyli się księża haliccy, sprawiło, że właśnie im powierzano najważniejsze posady w diecezji chełmskiej. Na początku 1875 roku większość dziekanów, członków konsystorza, nauczycieli Chełmskiego Seminarium oraz sam administrator eparchii unickiej byli pochodzenia halickiego ${ }^{18}$. Jak oceniała późniejsza prasa halicka z czasów wielkiej wojny, bez pomocy księży z Galicji Rosja nie byłaby w stanie „oprawosławić i zruszczyć Chełmszczyzny”19. Wśród 102 duchownych pochodzenia galicyjskiego tylko Emilian Piasecki i wyświęcony w Chełmie Józef Lipiński odmówili przejścia na prawosławie ${ }^{20}$.

Po likwidacji obrządku ,grecko-unickiego”, stosunek wobec „Galicjan” zaczął się szybko zmieniać. Między „dawnie prawosławnym” archijerejem warszawskim a partią Galicjan, na czele z biskupem lubelskim Marcelim (Popielem), od początku narastał konflikt. Przyczyną był wrogi stosunek prawosławnych elit eparchii chełmsko-warszawskiej do przybyszy z Austrii, a także wspieranie przez władze carskie planów upodobnienia miejscowego prawosławia do funkcjonującego w Cesarstwie. Wychowani w innych tradycjach Galicjanie gorzej posługiwali się językiem wielkorosyjskim oraz okazywali małą gorliwość w rozpowszechnianiu prawdziwego piękna

15 APL, KGL, 1883:240, k. 1-3.

16 Tamże, 1904:167, k. 1-2.

${ }^{17}$ W. Osadczy, dz. cyt., s. 218; W. Kołbuk, dz. cyt., s. 98-99.

18 A. Korobowicz, Kler greckounicki w Królestwie Polskim (1815-1875), „Rocznik Lubelski”, t. 9, 1966, s. 263-264.

${ }^{19}$ W. Osadczy, dz. cyt., s. 234.

${ }^{20}$ Tamże, s. 229. 
obrządku „grecko-rosyjskiego” wśród byłych unitów. Postawa duchowieństwa halickiego budziła wiele zastrzeżeń zarówno władz administracyjno-policyjnych, jak i samego arcybiskupa warszawskiego. Sporo kontrowersji wywoływała także postawa moralna Galicjan. Po 1875 roku coraz częściej zarzucano im brak energicznej pracy z „opornymi” unitami oraz to, że byli karierowiczami i zabiegali wyłącznie o poprawę swoich warunków materialnych. Problematyczne były również konsolidacja środowiska i utrzymywanie kontaktów z rodakami w Austrii. Dla większości urzędników rosyjskich i duchowieństwa prawosławnego Galicjanie pozostali obcymi. Jak pisał, przebywający w czasach likwidacji unii na terenie Chełmszczyzny, halicki działacz ukrainofilski Kornyło Ustijanowicz, ,już w Chełmie odczułem to przekonanie, że Moskale gardzą nami, że nas nie uważają za Rosjan. Natrząsali się z nas: «Co to za naród Galicjanie?... Polacy, nie Polacy, Ukraińcy, nie Ukraińcy, ... oni oddzielny narodek dla siebie»" ${ }^{21}$.

Mimo braku zaufania w stosunku do księży z Austrii, w drugiej połowie lat 70. nadal wielu alumnów pochodzenia halickiego wyświęcano w Chełmie. Związane było to z polityką biskupa lubelskiego Marcelego, który popierał swoich rodaków. Kiedy jednak w 1879 roku Marceli został przeniesiony do eparchii podolskiej, Galicjanie musieli pogodzić się z nowymi realiami. Nowym biskupem lubelskim, a równocześnie pierwszym wikariuszem z Cesarstwa, mianowany został były biskup jekaterynburski i wikariusz permski Modest (Strielbicki). Za rządów Modesta i jego następców liczba przybywających z Galicji księży i alumnów istotnie zmalała. Chociaż niektórych Galicjan wciąż wyświęcano w Chełmie, był to coraz częściej wyjątek, a nie reguła ${ }^{22}$. Nowa polityka państwa i władz eparchialnych wyraźnie wspierała duchownych ,dawnie prawosławnych”, sprowadzonych z guberni Cesarstwa.

Księża z Cesarstwa stanowili nowy element, wcześniej nieobecny na terenie diecezji chełmskiej. Ich masowy napływ zaczął się zaraz po utworzeniu eparchii chełmsko-warszawskiej. Większość nich pochodziła z guberni wołyńskiej. Podział duchowieństwa „dawnie prawosławnego" działającego w wikariacie lubelskim w roku 1877 według pochodzenia terytorialnego przedstawia tabela 2.

W okresie późniejszym spory odsetek stanowili również księża z guberni grodzieńskiej, kijowskiej, podolskiej, mińskiej, wileńskiej, czernihowskiej, połtawskiej, smoleńskiej oraz z guberni nieunickich Królestwa Polskiego. Wśród duchownych z Cesarstwa znaleźli się również księża z guberni twerskiej, moskiewskiej etc. Pojawienie się kleru z Cesarstwa na terenie wikariatu lubelskiego było spowodowane chęcią ostatecznego zbliżenia spolonizowanej Cerkwi na Chełmszczyźnie i Podlasiu z „dawnie prawosławnymi” obszarami Rosji. Wychowani w tradycjach

${ }^{21}$ K. N. Ustijanowicz, M. F. Rajewskij i rossijskij panslawizm. Spominki s pierieżytogo i pieriedumannogo, Lwow, s. 25-26.

${ }^{22}$ Jednymi z ostatnich księży pochodzących z Galicji, a pracujących w Chełmie, byli Mikołaj Taratuła i Orest Milkow, wyświęceni w latach 1895 i 1896. Zob.: Centralnyj Derżawnyj Istorycznyj Archiw Ukrajiny, m. Lwiw, f. 693, op. 1, spr. 590, k. 56. 
wielkorosyjskich księża z Cesarstwa cieszyli się nieporównywalnie większym zaufaniem władz duchownych i administracyjnych niż skompromitowani polonofilstwem księża miejscowi i podejrzani o materializm Galicjanie. W niedługim czasie kler „dawnie prawosławny” zaczął wypierać księży innych grup, przede wszystkim Galicjan, z posad wcześniej przez nich obsadzonych. W następnych dziesięcioleciach odsetek księży z Cesarstwa wzrastał proporcjonalnie do zmniejszenia się liczby duchownych z Galicji w wikariacie lubelskim. W odróżnieniu od duchowieństwa halickiego, znakomita większość księży „dawnie prawosławnych” została wyświęcona poza Chełmszczyzną. Tylko część alumnów z tej grupy, urodzonych w warszawskiej części eparchii, otrzymała pierwsze skierowania na parafie pounickie. Warto również zaznaczyć, że ci duchowni mieli wcześniejszy kontakt tylko z napływową ludnością Królestwa Polskiego i słabo orientowali się w realiach pracy z byłą ludnością unicką. Podobne zarzuty stawiano czasami całemu klerowi ,dawnie prawosławnemu” działającemu wówczas w wikariacie, co można dostrzec w ocenie niektórych krytyków polityki wyznaniowej caratu na Chełmszczyźnie i Podlasiu ${ }^{23}$.

Mimo to właśnie duchowieństwo z Cesarstwa miało zdominować życie cerkiewne w wikariacie lubelskim. Jak widać z tabeli 3., w ciągu 27 lat (od 1877 do 1904 roku) liczba duchownych z Cesarstwa zwiększyła się prawie trzykrotnie (od 43 do 118). W tym samym czasie liczba Galicjan zmniejszyła się o $35 \%$ (ze 129 do 84). Najciekawsze zmiany odnotować można, badając grupę księży miejscowych. Jeśli w latach 1877-1897 liczba tych księży uległa znacznemu zmniejszeniu, po 1897 roku znów zaczęła się powiększać i w 1904 roku przekroczyła stan z roku 1877. W latach 1897-1904 liczba duchowieństwa „miejscowego” zwiększyła się o 28\% (z 79 do 110), z czego można wnioskować o zmianie polityki wobec duchowieństwa urodzonego na ziemiach byłej diecezji chełmskiej. Przyczyną takiego stanu rzeczy miało stać się aktywne zachęcanie młodzieży z dawnych terenów unickich, wychowanej w tradycjach prawosławnych, do służby kapłańskiej. Większość tej młodzieży skończyła naukę w prawosławnym Chełmskim Seminarium, nie pamiętała czasów unii, więc uważano ją za grupę politycznie wiarygodną. Dodatkowo symbolizować to miało zwycięstwo polityki depolonizacji Chełmszczyzny. Z tabeli 3. wynika, że napływ kleru „dawnie prawosławnego” do wikariatu lubelskiego w latach 1897-1904 uległ zahamowaniu, a jedyną grupą księży, która wzrastała w siłę, stanowili księża miejscowi ${ }^{24}$.

Jak widać ze wskazanej tabeli, w roku 1904 w eparchii warszawsko-chełmskiej pracowało jeszcze wielu Galicjan. Mimo stałych konfliktów z księżmi innych grup i niezadowolenia z nowej sytuacji politycznej w diecezji po ustąpieniu biskupa Marcelego, większość księży halickich pozostała w Królestwie Polskim i pracowała w swoich parafiach aż do śmierci. Chociaż w roku 1904 w wikariacie lubelskim

${ }^{23}$ I. I. Soniewicki, Chołmszczina. Ocierki proszłago, S.-Pietierburg 1912, s. 39, 41-42.

${ }^{24}$ Należy pamiętać, że wśród księży „miejscowych” znalazła się również pewna liczba osób pochodzących z rodzin emigrantów, którzy pozostali na Chełmszczyźnie. 
pozostawało 84 duchownych pochodzenia halickiego, większość z nich była już osobami po pięćdziesiątym roku życia.

Analiza pochodzenia społecznego duchowieństwa prawosławnego wyraźnie pokazuje, że jego charakter niewiele różnił się od charakteru duchowieństwa unickiego w okresie wcześniejszym. Księża prawosławni, podobnie jak niegdyś greckokatoliccy, w większości pochodzili z rodzin duchownych ${ }^{25}$. Jak widać w tabeli 4., zdecydowaną większość duchowieństwa działającego w parafiach pounickich w 1877 roku stanowili synowie byłych księży. Dodatkowo trzech duchownych pochodziło z rodzin psalmistów (1 Galicjanin i 2 z Cesarstwa) oraz dwóch duchownych z Cesarstwa urodziło się w rodzinach zasłużonych protojerejów. Ogólnie, w 1877 roku w parafiach pounickich pracowało nie mniej niż 75,3\% księży z rodzin duchownych. Warto zaznaczyć, że w 1877 roku wśród duchowieństwa pochodzenia świeckiego dominowali księża z Galicji - w grupie tej znalazł się m.in. jedyny duchowny z rodziny nauczycielskiej, Michał Somik. Wśród Galicjan było również najwięcej osób pochodzenia szlacheckiego (8 księży), chociaż niemało wywodziło się z rodzin mieszczańskich i chłopskich (17 i 8). W tym też roku w grupie księży miejscowych było zaledwie 19 osób pochodzenia świeckiego (10 z rodzin mieszczańskich, 3 z chłopskich, 1 z szlachty). Pochodzenia 22 duchownych nie udało się nam zidentyfikować.

Tzw. duchowieństwo „dawnie prawosławne”, obecność którego na terenach pounickich od 1875 roku ciągle się powiększała, warto podzielić na dwie grupy wewnętrzne. Pierwsza obejmowała kler działający na terenach pounickich prawie w całości złożony z przybyszy z Cesarstwa. Druga z kolei składała się z tych księży, którzy i wcześniej działali w Królestwie Polskim. W jej skład wchodziło przede wszystkim duchowieństwo „dawnie prawosławne” byłej eparchii warszawskiej i nowogeorgiewskiej, pracujące w parafiach rozmieszczonych na Chełmszczyźnie i Podlasiu, a później przyłączonych do wikariatu lubelskiego. Jeśli pierwsza grupa w większości pochodziła z rodzin duchownych, wśród księży „,dawnie prawosławnych" drugiej grupy nierzadko były osoby z rodzin wojskowych i urzędników. Duchowni ostatniej grupy zazwyczaj pracowali w parafiach wojskowych byłej eparchii warszawskiej, ale czasami obejmowali i parafie pounickie wikariatu lubelskiego ${ }^{26}$.

$\mathrm{W}$ ostatnich latach istnienia eparchii chełmsko-warszawskiej struktura społeczna duchowieństwa prawosławnego nie uległa poważnym zmianom. W warunkach mocnego przywiązania do tradycji rodzinnych oraz małej mobilności wśród ludności Królestwa Polskiego większość duchowieństwa eparchii kontynuowała zawód swoich ojców. Różnicą było jednak pojawienie w 1904 roku wśród duchowieństwa prawosławnego osób pochodzenia wojskowego ( $2,9 \%$ od liczby księży) i urzędniczego $(5,8 \%)$, co świadczyło o rozszerzeniu sieci parafialnej wikariatu lubelskiego na parafie byłej eparchii warszawskiej i nowogeorgiewskiej, znajdujące się na terytorium

${ }^{25}$ W. Kołbuk, dz. cyt., s. 37.

${ }^{26}$ Przykładem takich duchownych mogą być ks. M. Czernikow, od 1899 roku proboszcz parafii Hola, albo T. Miszczenko, od 1898 roku proboszcz w Kodniu. Zob.: APL, KV, sygn. 103, 983. 
guberni lubelskiej i siedleckiej. Oprócz tego istotnie wzrosła liczba księży pochodzenia chłopskiego (od 4,5 do 9,9\%), co mogło świadczyć o szerszym zainteresowaniu prawosławnych chłopów - zarówno pochodzących z Cesarstwa, jak i miejscowych karierą duchowną na Chełmszczyźnie i Podlasiu. Warto zaznaczyć, że dla wielu włościan tego czasu kariera duchowna oznaczała możliwości awansu społecznego.

W tym czasie nadal pozostawały znaczne różnice pomiędzy poszczególnymi grupami duchowieństwa prawosławnego działającego na Chełmszczyźnie i Podlasiu, co nie oznacza, że nie istniała pomiędzy nimi współpraca. Młodsi księża miejscowi, którzy ukończyli kurs nauk w Chełmskim Seminarium, zmienionym na wzór uczelni prawosławnych Cesarstwa, niewątpliwie musieli bardziej upodobnić się do duchowieństwa prawosławnego spoza Królestwa Polskiego. To samo dotyczyło wielu młodych księży z Galicji, którzy nie uczyli się i nie mieli praktyki duszpasterskiej poza Chełmszczyzną. Oprócz tego wart uwagi jest fakt zawierania przez część duchowieństwa halickiego małżeństw z kobietami z byłej diecezji chełmskiej oraz Cesarstwa, co w konsekwencji miało ich zbliżać z ludnością ruską Królestwa i Rosji. Z drugiej strony, większość księży z Cesarstwa, którzy emigrowali do eparchii chełmsko-warszawskiej, pod wpływem nowego otoczenia przystosowywała się do realiów byłych terenów unickich. Nieznaczne zbliżenie pomiędzy trzema grupami duchowieństwa prawosławnego nie mogło jednak przełamać dzielących ich mocnych barier wewnętrznych, które powodowały częste konflikty (szczególnie pomiędzy Galicjanami i ,dawnie prawosławnymi”) i dochodziło do nich także po roku 1905.

Jak widzimy, w latach 1875-1905 odbywał się proces przekształcania byłego kleru greckokatolickiego Królestwa Polskiego w duchowieństwo prawosławne. Chociaż wśród duchownych eparchii chełmsko-warszawskiej w 1904 roku nadal pozostawało wielu księży z czasów sprzed likwidacji unii, zmiany personalne duchowieństwa, a także jego przemieszczenie się, kontakt z ludnością miejscową i księżmi z innych grup wpływały na ukształtowanie jednej wspólnoty kleru prawosławnego, pracującego z byłymi unitami Królestwa Polskiego. Równocześnie pozostawały istotne różnice pomiędzy duchowieństwem różnego pochodzenia terytorialnego, które i po 1905 roku dawały o sobie znać. W latach 1875-1905 uwidocznił się proces starzenia się duchowieństwa wikariatu lubelskiego, co w porównaniu z 1875 rokiem (7,91\%) doprowadziło w roku 1904 do istotnego wzrostu liczby księży w wieku 50-60 lat (29,71\%) Przyczyną tego było zmniejszenie się liczby młodych alumnów i księży z Galicji przy jednoczesnym napływie doświadczonych duchownych z Cesarstwa. Z innej strony w latach 1897-1904 istotnie wzrosła liczba alumnów Chełmskiego Seminarium Duchownego pochodzenia miejscowego, co świadczyło zarówno o rozwoju systemu edukacji prawosławnej, jak i o szerszym przyciąganiu ludności miejscowej do pracy duchownej. Przetworzenie byłych unickich księży diecezji chełmskiej w prawosławnych, zasilenie szeregów lojalnego duchowieństwa poprzez przesiedlenie księży z Cesarstwa i wyświęcenie nowych proboszczów z alumnów miejscowych, wszystko to wzmacniało kadrę sojuszników caratu na polsko-ruskim pograniczu w polityce ostatecznej integracji byłych unitów z prawosławiem i rosyjskością. 
Faktycznie w latach 1875-1905 na terenie Królestwa Polskiego doszło do powstania nowej klasy społecznej o charakterze rosyjskim, będącej opoką i nadzieją władz carskich w tym trudnym regionie.

Tabela 1: Duchowieństwo dekanatów znajdujących się w wikariacie lubelskim według wieku

\begin{tabular}{|c|c|c|c|c|c|c|c|c|}
\hline \multirow{2}{*}{ Lata } & \multicolumn{8}{|c|}{ Wiek duchowieństwa } \\
\cline { 2 - 9 } & $20-30$ & $30-40$ & $40-50$ & $50-60$ & $60-70$ & Ponad 70 & Brak inf. & Razem \\
\hline 1877 & 98 & 97 & 42 & 22 & 12 & 2 & 5 & 278 \\
\hline 1884 & 44 & 117 & 68 & 38 & 15 & 7 & 9 & 298 \\
\hline 1891 & 28 & 80 & 111 & 44 & 21 & 6 & 11 & 301 \\
\hline 1897 & 36 & 52 & 100 & 70 & 24 & 7 & 13 & 302 \\
\hline 1904 & 43 & 63 & 59 & 93 & 40 & 10 & 5 & 313 \\
\hline
\end{tabular}

Źródło: APL, KV, sygn. 2, 20, 30, 41, 52, 69, 81, 93, 103, 115, 128, 140, 149, 162, 180, 271, 281, 293, $303,317,335,347,358,372,389,401,413,426,435,445,462,471,484,497,516,527,537,547,558,569$, $589,601,617,630,633,667,679,686,699,708,719,730,743,754,766,774,787,798,807,817,825$, $838,852,863,873,885,896,906,917,927,941,956,963,972,982,992,1004,1015,1026,1038,1049$.

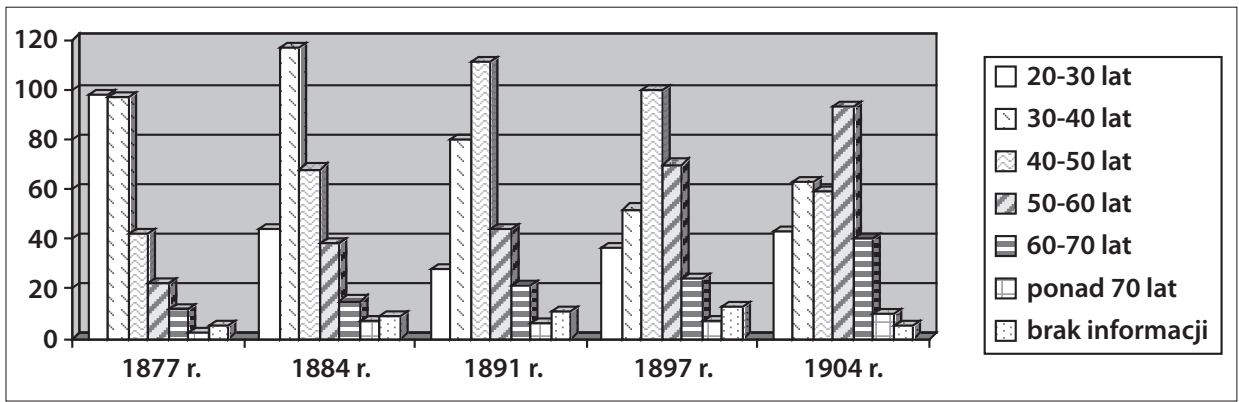

Diagram 1: Zmiany piramidy wiekowej duchowieństwa parafialnego wikariatu lubelskiego w latach 1877-1904

Tabela 2: Kler „dawnie prawosławny" działający w parafiach pounickich wikariatu lubelskiego w 1877 roku według guberni pochodzenia

\begin{tabular}{|c|c|c|c|c|c|c|c|}
\hline Gubernia & $\begin{array}{c}\text { wo- } \\
\text { łyńska }\end{array}$ & $\begin{array}{c}\text { gro- } \\
\text { dzieńska }\end{array}$ & kijowska & wileńska & $\begin{array}{c}\text { czerni- } \\
\text { howska }\end{array}$ & twerska & razem \\
\hline Liczba księży & 27 & 8 & 4 & 2 & 1 & 1 & 43 \\
\hline$\%$ & 62,79 & 18,60 & 9,30 & 4,65 & 2,33 & 2,33 & 100 \\
\hline
\end{tabular}

Źródło: APL, KV, sygn. 2, 115, 271, 401, 527, 601, 686, 743, 798, 896, 1004. 
Tabela 3: Zmiany duchowieństwa parafialnego wikariatu lubelskiego według pochodzenia terytorialnego

\begin{tabular}{|c|c|c|c|c|c|c|c|c|c|c|}
\hline \multirow[t]{3}{*}{ lata } & \multicolumn{8}{|c|}{ grupy duchowieństwa według pochodzenia terytorialnego } & \multirow{2}{*}{\multicolumn{2}{|c|}{ razem }} \\
\hline & \multicolumn{2}{|c|}{ „miejscowi” } & \multicolumn{2}{|c|}{ „Galicjanie” } & \multicolumn{2}{|c|}{$\begin{array}{c}\text { „z dawna } \\
\text { prawosławni” }\end{array}$} & \multicolumn{2}{|c|}{$\begin{array}{l}\text { nieokreślone } \\
\text { pochodzenie } \\
\text { terytorialne }\end{array}$} & & \\
\hline & ilość & $\%$ & ilość & $\%$ & ilość & $\%$ & ilość & $\%$ & ilość & $\%$ \\
\hline 1877 & 96 & 34,53 & 129 & 46,40 & 52 & 18,71 & 1 & 0,36 & 278 & 100 \\
\hline 1884 & 88 & 29,53 & 130 & 43,62 & 76 & 25,50 & 4 & 1,35 & 298 & 100 \\
\hline 1891 & 85 & 28,24 & 117 & 38,87 & 97 & 32,23 & 2 & 0,66 & 301 & 100 \\
\hline 1897 & 79 & 26,16 & 104 & 34,44 & 118 & 39,07 & 1 & 0,33 & 302 & 100 \\
\hline 1904 & 110 & 35,14 & 84 & 26,84 & 118 & 37,70 & 1 & 0,32 & 313 & 100 \\
\hline
\end{tabular}

Źródło: APL, KV, sygn. 2, 20, 30, 41, 52, 69, 81, 93, 103, 115, 128, 140, 149, 162, 180, 271, 281, 293, $303,317,335,347,358,372,389,401,413,426,435,445,462,471,484,497,516,527,537,547,558,569$, $589,601,617,630,633,667,679,686,699,708,719,730,743,754,766,774,787,798,807,817,825$, $838,852,863,873,885,896,906,917,927,941,956,963,972,982,992,1004,1015,1026,1038,1049$.

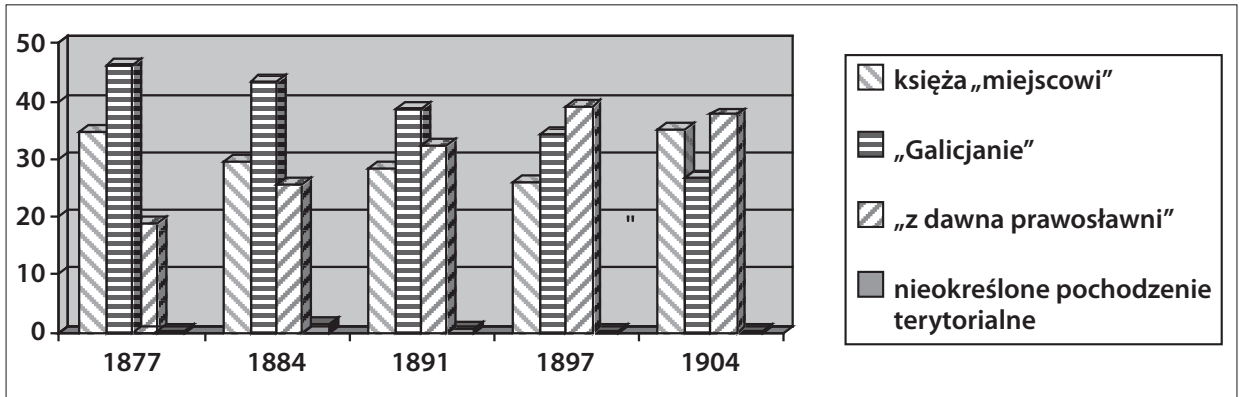

Diagram 2: Grupy terytorialne duchowieństwa parafialnego w wikariacie lubelskim w latach 1877-1904 (w proc.) 
Tabela 4: Pochodzenie społeczne duchowieństwa pracującego w parafiach guberni lubelskiej i siedleckiej w latach 1877 i 1904

\begin{tabular}{|c|c|c|c|c|c|c|c|c|c|c|c|c|}
\hline \multirow{4}{*}{ Pochodzenie } & \multicolumn{8}{|c|}{ Regiony } & & & & \\
\hline & \multicolumn{4}{|c|}{ gub. siedlecka } & \multicolumn{4}{|c|}{ gub. lubelska } & \multicolumn{4}{|c|}{ Razem } \\
\hline & \multicolumn{2}{|c|}{1877} & \multicolumn{2}{|c|}{1904} & \multicolumn{2}{|c|}{1877} & \multicolumn{2}{|c|}{1904} & \multicolumn{2}{|c|}{1877} & \multicolumn{2}{|c|}{1904} \\
\hline & $\begin{array}{c}\text { licz- } \\
\text { ba }\end{array}$ & $\%$ & $\begin{array}{c}\text { licz- } \\
\text { ba }\end{array}$ & $\%$ & $\begin{array}{c}\text { licz- } \\
\text { ba }\end{array}$ & $\%$ & $\begin{array}{c}\text { licz- } \\
\text { ba }\end{array}$ & $\%$ & $\begin{array}{c}\text { licz- } \\
\text { ba }\end{array}$ & $\%$ & $\begin{array}{c}\text { licz- } \\
\text { ba }\end{array}$ & $\%$ \\
\hline $\begin{array}{l}\text { Duchowni } \\
\text { i psalmiści }\end{array}$ & 87 & 74,4 & 92 & 66,7 & 102 & 67,1 & 114 & 65,1 & 189 & 70,3 & 206 & 65,8 \\
\hline Chłopi & 5 & 4,3 & 15 & 10,9 & 7 & 4,6 & 16 & 9,2 & 12 & 4,5 & 31 & 9,9 \\
\hline Mieszczanie & 8 & 6,8 & 7 & 5,1 & 20 & 13,2 & 16 & 9,2 & 28 & 10,4 & 23 & 7,3 \\
\hline Inteligencja & 1 & 0,9 & 4 & 2,9 & 0 & 0 & 4 & 2,3 & 1 & 0,4 & 8 & 2,6 \\
\hline Ziemiaństwo & 4 & 3,4 & 0 & 0 & 6 & 3,9 & 6 & 3,4 & 10 & 3,7 & 6 & 1,9 \\
\hline Stan wojskowy & 0 & 0 & 6 & 4,3 & 0 & 0 & 3 & 1,7 & 0 & 0 & 9 & 2,9 \\
\hline Urzędnicy & 0 & 0 & 12 & 8,7 & 0 & 0 & 6 & 3,4 & 0 & 0 & 18 & 5,8 \\
\hline Świeckie nieznane & 5 & 4,3 & 0 & 0 & 2 & 1,3 & 2 & 1,1 & 7 & 2,6 & 2 & 0,6 \\
\hline Brak inf. & 7 & 5,9 & 2 & 1,4 & 15 & 9,9 & 8 & 4,6 & 22 & 8,1 & 10 & 3,2 \\
\hline Razem & 117 & 100 & 138 & 100 & 152 & 100 & 175 & 100 & 269 & 100 & 313 & 100 \\
\hline
\end{tabular}

Źródło: APL, KV, sygn. 1, 52, 103, 115, 162, 180, 271, 316, 372, 389, 400, 445, 497, 516, 526, 569, 589, $600,679,686,730,742,787,798,838,885,895,941,982,992,1004,1049$. 